\title{
WHAT THEY SAY AND WHAT THEY DO: COMPARING DESTINATION MARKETING ACTIVITIES RELATED TO MOVIE TOURISM IN CROATIA'S ZADAR COUNTY
}

\author{
Martina Furčić \\ Ljudevit Pranić
}

https://doi.org//10.20867/tosee.06.19

\begin{abstract}
Purpose - While influence of movies and television on destination image and tourist destination choice is well documented in tourism literature, understanding of the perceptions of destination marketers in movie locations remains an emerging area of inquiry. Consequently, the objectives of this study are: (a) to assess the perceptions of key destination stakeholders regarding the level of integration of movie-induced tourism and destination marketing after a movie's release, and (b) to compare their perceptions to what can actually be observed, in a relatively popular movieshooting destination such as Zadar County (ZC), Croatia.

Methodology - Using the Hudson and Ritchie (2006a) model for exploiting movie marketing opportunities, this study employs multimethod research, combining interviews and observation. First, 10 representatives of the tourism and movie industries in ZC are interviewed about the following four factors: movie-induced tourism, marketing activities, branding, and stakeholder involvement. Second, seven tourism-related websites in ZC are analyzed for presence and quality of the movie-related promotional content.

Findings - Interviews reveal that key stakeholders (1) embrace the notion of movie-induced tourism, (2) find movie tourism to be well integrated into destination marketing activities, (3) believe that movies are an integral part of ZC's place branding strategy, and (4) perceive that tourism and movie stakeholders actively and systematically collaborate on advancing the movie tourism. However, website content analysis reveals exactly the opposite.

Contribution - Theoretically, this research sheds light on the destination marketers' perspectives in regards to movie-induced tourism. Practically, it offers insights on how to tap the potential benefits of movie tourism.

Keywords: Film tourism, movie-induced tourism, tv tourism, tourism stakeholders, destination branding image, destination marketing.
\end{abstract}

\section{INTRODUCTION}

Non-tourist directed information sources, such as movies and television, may generate faster market penetration and higher interest in a destination in a way that destination marketers cannot afford to do with the traditional tourist-directed methods (Hahm and Wang 2011; Tooke and Baker 1996). Hence, it is generally well accepted that tourism organizations can use movies and television series as springboards to increase tourist patronage to a featured location (Beeton 2010, 2006; Busby and Klug 2001; Cardoso et al. 2017; Carl et al. 2007; Hudson and Ritchie 2006a, 2006b; Özdemir and Adan 2014). Movie-induced tourism, also known as film-induced tourism (Beeton 2006), screen 
ToSEE - Tourism in Southern and Eastern Europe, Vol. 6, pp. 283-302, 2021.

M. Furčić, Lj. Pranić: WHAT THEY SAY AND WHAT THEY DO: COMPARING DESTINATION ...

tourism (Connell and Meyer 2009), and media-related tourism (Busby and Klug 2001), can be understood as "tourist visits to a destination or attraction as a result of the destination's being featured on television, video, DVD or the movie screen" (Hudson and Ritchie 2006a, 387).

Since the beginning of the scholarly research on movie-induced tourism in the $1990 \mathrm{~s}$ (Beeton 2006), there is a growing interest in this area of study (Michael et al. 2020). According to Hudson and Ritchie (2006a), the literature on movie tourism can be classified into four broad categories: (1) the influence of movie on the decision to travel (2) movie tourists themselves, (3) the impacts of movie tourism on visitation numbers and on residents, and (4) destination marketing activities related to movie tourism. The focus of this article will be on the latter category related to destination marketing.

Destination marketing opportunities arise not only when the motion picture is being premiered, but also each time it is rebroadcasted. Thus, the benefits from the visibility that movies provide can be enduring, drawing visitors year after year (Riley at al. 1998). Moreover, additional businesses and services can be created through movie tourism that in turn can alleviate the problems of seasonality. While some Destination Marketing Organizations (DMOs) have harnessed the power of movies and television in luring a significant number of tourists to a destination, others have neglected this very effective form of publicity (Hudson and Ritchie 2006a). Therefore, the important role of DMOs within the movie-induced tourism will be investigated in detail in this article.

The two main objectives of this study are: (a) to assess the perceptions of key destination stakeholders regarding the level of integration of movie-induced tourism and destination marketing after a movie's release, and (b) to compare their perceptions to what can actually be observed, in a relatively popular movie-shooting destination such as Zadar County (ZC), Croatia.

\section{MOVIE-INDUCED TOURISM AND DESTINATION MARKETING}

There is a general agreement among scholars and laymen that watching movies or series has a profound influence on travel behaviors (Spears et al. 2013). The numbers speak for themselves; in 2012, the number of tourists motivated by movie tourism has increased from 40 million in 2012 (Modiano 2013) to 80 million in 2018 (TCI 2018). However, it was not until the 1980s that movie tourism was first mentioned in the academic literature (O'Connor 2010) and it is believed that Field of Dreams (a 1989 movie shot in the U.S. state of Iowa), JFK (1991, Texas), The Last of the Mohicans (1992, North Carolina), The Fugitive (1993, North Carolina), and many more, together mark a considerable milestone in the development of a new travel trend (Riley et al. 1998).

Hudson and Ritchie (2006b) link the development of movie tourism to the development of the American blockbuster, starting with Jaws (1975), which opened in 465 movie theaters in the U.S., to Lord of the Rings, shown across 10,000 theaters worldwide almost 30 years later. At the $10^{\text {th }}$ International Film Tourism Convention (Ita. Cineturismo), Ischia Film Festival, held in 2012 on the island of Ischia, it was said that Roman Holiday, a 1953 American movie set in Rome, launched the first wave of American tourists to 
ToSEE - Tourism in Southern and Eastern Europe, Vol. 6, pp. 283-302, 2021.

M. Furčić, Lj. Pranić: WHAT THEY SAY AND WHAT THEY DO: COMPARING DESTINATION ...

Italy (Carlucci 2012). On the African continent, Out of Africa (1985), set in Kenya and Tanzania, has been credited for attracting American tourists there. Similarly, Gorilla in the Mist (1988), increased tourism in Rwanda by $20 \%$ (O’Connor 2010).

Movies that nurture an authentic image of the destination and depict the essence of the place have a better chance of attracting movie tourists, and this was used by Australia with Crocodile Dundee (1986) to stimulate wider international interest by depicting ancient and modern culture (Hudson and Ritchie 2006b). Other factors affecting movie tourism are the amount of exposure to a movie or series, and successfully linking a movie to a particular location, such as Lord of the Rings and New Zealand (NZ), and Braveheart and Scotland (O'Connor 2010).

The benefits of using movies for destination promotion are obvious; they ensure the viewer's identification with the destination through an emotional connection to the story and characters. Morgan and Pritchard (1998) believe that placing a destination in a movie is important for destination marketing, and this is also the ultimate placement of a tourism product. DMOs need to participate in various marketing activities before and after the movie's release because movie images last for decades, ensure the promotion of a place and create a destination identity, and the film acts as an advertisement, watched by a vast number of people, an audience that would otherwise be impossible to reach through conventional destination marketing campaigns (Hudson and Ritchie 2006b).

In order to study the marketing of a destination through movies as a way for DMOs to attract movie tourists, Hudson and Ritchie (2006a) developed a conceptual framework for understanding movie-induced tourism. According to the model (Figure 1), movie tourism is driven by the following five factors: destination marketing activities, destination attributes, movie-specific factors, film commission and government efforts, and location feasibility. In terms of destination marketing activities, DMOs can employ a range of marketing activities before and after a movie's release. The focus of this article is on the destination marketing activities related to movie tourism after release of a movie. 
ToSEE - Tourism in Southern and Eastern Europe, Vol. 6, pp. 283-302, 2021.

Figure 1: Film tourism: a model for exploiting film marketing opportunities

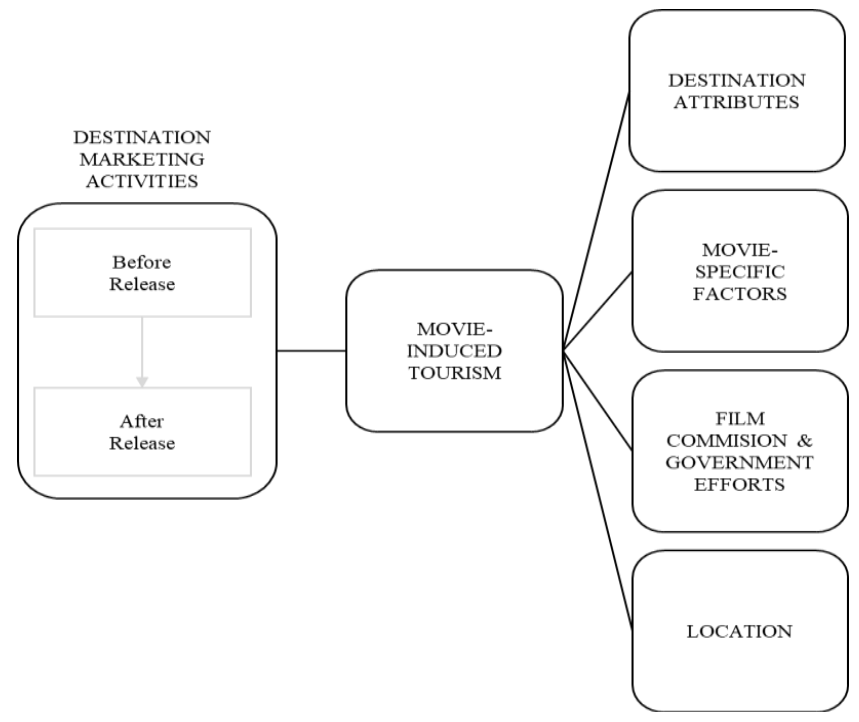

Source: Hudson and Ritchie (2006a)

After release of a movie, DMOs can exploit movie marketing opportunities in a number of ways. A destination can brand itself around a movie. For instance, during and after release of the movie Braveheart, the Scottish Tourist Board branded itself as Braveheart Country (Grihault 2003). Promoting the destination based on a movie can be leveraged at every release and re-release window, such as when the movie is shown on free television even decades after the initial release (Hudson and Ritchie 2006a). Walking tours and other guided tours are another way to attract attention to a destination. In Croatia, a local tour company gameofthronestourcroatia.com capitalized on the success of Game of Thrones, creating popular guided tours of the medieval Klis Fortress, worldrenown Dubrovnik Old City Walls, Diocletian's Palace built for the Roman emperor Diocletian in Split, a local quarry, and many other actual shooting locations.

Lodging facilities, attractions, and museums used in movies or by movie actors and crews are often promoted to the public to generate patronage. In Tunisia, Star Wars aficionados can stay at hotel Sidi Driss used as the location Luke Skywalker's childhood home in Star Wars Episode IV: A New Hope. In some instances, new attractions are developed and built based on a popular movie. Avatar Flight of Passage, based on the 2009 blockbuster Avatar, opened to the public at Disney World's Animal Kingdom theme park in 2017.

Finally, promoting the movie on a DMO website is also deemed important. In NZ, newzealand.com spotlights Home of Middle-earth and Film in NZ under Things to do on its homepage. Similarly, visitscotland.com specifically promotes Film \& TV Locations for James Bond's Skyfall and Harry Potter movies, and Outlander and The Crown television series, all under the See \& Do menu section on its homepage. 
ToSEE - Tourism in Southern and Eastern Europe, Vol. 6, pp. 283-302, 2021.

M. Furčić, Lj. Pranić: WHAT THEY SAY AND WHAT THEY DO: COMPARING DESTINATION ...

In terms of the scholarly research on the destination marketing activities factor of the Hudson and Ritchie (2006a) conceptual framework, systematic literature reviews by Cardoso et al. (2017) and Domínguez-Azcue et al. (2021) provide a closer look into the state of the art of research on the movie-induced tourism. According to Cardoso et al. (2017), there are two major streams of research on movie tourism. One group of articles explore the image and marketing of tourism destination and how movies may amplify both. The other group of articles focus on the ways movies induce tourism. Among the themes analyzed in the studies reviewed by Cardoso et al. (2017), marketing activities by DMOs went unidentified. Moreover, of the 39 articles systematically reviewed, 20 were theoretical in nature, 17 were quantitative, and two were qualitative. No study employed both quantitative and qualitative analyses.

In Domínguez-Azcue et al. (2021), the critical role of DMOs and the importance of the collaboration between DMOs and film commission in ensuring a destination's success is clearly recognized. However, of the 118 articles systematically reviewed, only 20 deal with marketing and promotion. Among these, the vast majority use anecdotal evidence and offer prescriptive advice on how to successfully promote a destination before, during or after a move production. No study in Domínguez-Azcue et al. (2021) explores whether and to what degree the destination's stated or planned marketing activities have been implemented in reality. That said, a separate search of academic databases uncovered one scholarly article that is relevant to our study, an article that was not covered by either Cardoso et al. (2017) or Domínguez-Azcue et al. (2021). Thus, in a study of movieinduced marketing activities undertaken by DMOs in Egypt, it was revealed that DMOs did a poor job in promoting Egypt (El Samie Mohamed 2016). However, the findings were based on face-to-face interviews with key experts in the Egyptian DMOs.

Notwithstanding the relatively voluminous academic research on movie-induced tourism, scholars have largely not studied why some destinations perform better than others in attracting movie tourists. One way of investigating this important issue is to take a closer look at the potential discrepancies between destination marketers' perceptions and their actual behaviors. However, in order to produce more valid and credible findings, one should employ more than one method to gather data, such as interviews, observations, questionnaires, and documents (O'Connor et al. 2008; Özdemir and Adan 2014). Despite an array of literature covering various aspects of the movie tourism phenomenon, there appears to be a gap in the available literature on what DMOs say and what they actually do in terms of exploiting movie marketing opportunities. The main objectives of this article, therefore, are (a) to assess the perceptions of key destination stakeholders regarding the level of integration of movie-induced tourism and destination marketing after a movie's release, and (b) to compare their perceptions to what can actually be observed, in a relatively popular movie-shooting destination such as Zadar County (ZC), Croatia.

\section{WINNETOU AND ZADAR COUNTY}

Winnetou is a fictional Native American hero and a central figure in a number of adventure novels written in German by Karl Friedrich May (1842-1912). With his novels translated into three dozen foreign languages and over 200 million copies sold 
ToSEE - Tourism in Southern and Eastern Europe, Vol. 6, pp. 283-302, 2021.

M. Furčić, Lj. Pranić: WHAT THEY SAY AND WHAT THEY DO: COMPARING DESTINATION ...

worldwide, he is one of the best-selling German writers ever. Many of his novels were adapted for western movies and television miniseries (Table 1). In Germany, the Winnetou movies are regarded as the most popular motion pictures of all time.

Table 1: List of Winnetou movies

\begin{tabular}{|c|c|c|c|}
\hline $\begin{array}{l}\text { Movie Title } \\
\text { (in German original) }\end{array}$ & $\begin{array}{l}\text { Movie Title } \\
\text { (in English) }\end{array}$ & $\begin{array}{c}\text { Release } \\
\text { Year }\end{array}$ & $\begin{array}{l}\text { Filming } \\
\text { locations }\end{array}$ \\
\hline Der Schatz im Silbersee & The Treasure of Silver Lake & 1962 & $\begin{array}{l}\text { Croatia \& } \\
\text { Germany }\end{array}$ \\
\hline Winnetou 1. Teil & Apache Gold & 1963 & $\begin{array}{l}\text { Croatia \& } \\
\text { Germany }\end{array}$ \\
\hline Old Shatterhand & Apaches' Last Battle & 1964 & Croatia \& UK \\
\hline Winnetou -2 . Teil & Last of the Renegades & 1964 & Croatia \& UK \\
\hline Unter Geiern & Frontier Hellcat & 1964 & $\begin{array}{l}\text { Croatia \& } \\
\text { Germany }\end{array}$ \\
\hline Der Ölprinz & Rampage at Apache Wells & 1965 & Croatia \\
\hline Winnetou -3 . Teil & $\begin{array}{l}\text { Winnetou: The Desperado } \\
\text { Trail }\end{array}$ & 1965 & $\begin{array}{l}\text { Croatia \& } \\
\text { Germany }\end{array}$ \\
\hline Old Surehand 1. Teil & Flaming Frontier & 1965 & $\begin{array}{l}\text { Croatia \& } \\
\text { Germany }\end{array}$ \\
\hline $\begin{array}{l}\text { Winnetou und das Halbblut } \\
\text { Apanatschi }\end{array}$ & Winnetou and the Crossbreed & 1966 & $\begin{array}{l}\text { Croatia \& } \\
\text { Germany }\end{array}$ \\
\hline $\begin{array}{l}\text { Winnetou und sein Freund Old } \\
\text { Firehand }\end{array}$ & Winnetou and Old Firehand & 1966 & $\begin{array}{l}\text { Croatia \& } \\
\text { Germany }\end{array}$ \\
\hline $\begin{array}{l}\text { Winnetou und Shatterhand im Tal } \\
\text { der Toten }\end{array}$ & The Valley of Death & 1968 & Croatia \\
\hline Winnetou - Eine neue Welt & Winnetou - A New World & 2016 & $\begin{array}{l}\text { Croatia \& } \\
\text { Germany }\end{array}$ \\
\hline $\begin{array}{l}\text { Winnetou - das Geheimnis vom } \\
\text { Silbersee }\end{array}$ & $\begin{array}{l}\text { Winnetou - The Secret of } \\
\text { Silver Lake }\end{array}$ & 2016 & $\begin{array}{l}\text { Croatia \& } \\
\text { Germany }\end{array}$ \\
\hline Winnetou - Der letzte Kampf & Winnetou - The Final Battle & 2016 & $\begin{array}{l}\text { Croatia \& } \\
\text { Germany }\end{array}$ \\
\hline
\end{tabular}

Source: Wikipedia and MMC https://www.mmc.de/en/winnetou-der-mythos-lebt-ab-dem-25-12-als-eventdreiteiler-bei-rtl/

Throughout the 1960's (1963-1968), 11 Winnetou movies were filmed in Croatia. In 2016, Germany's largest private free-to-air television network RTL shot another Winnetou movie trilogy, again in Croatia. Principal shooting usually took place in the breathtaking karst river canyon inside Paklenica National Park, with approximately twothirds of the park located near Starigrad Paklenica municipality in ZC, and the remaining one-third located in the adjacent Lika-Senj County (Figure 2). 
ToSEE - Tourism in Southern and Eastern Europe, Vol. 6, pp. 283-302, 2021.

\section{Figure 2: Geographical area under study - Zadar County, Croatia}

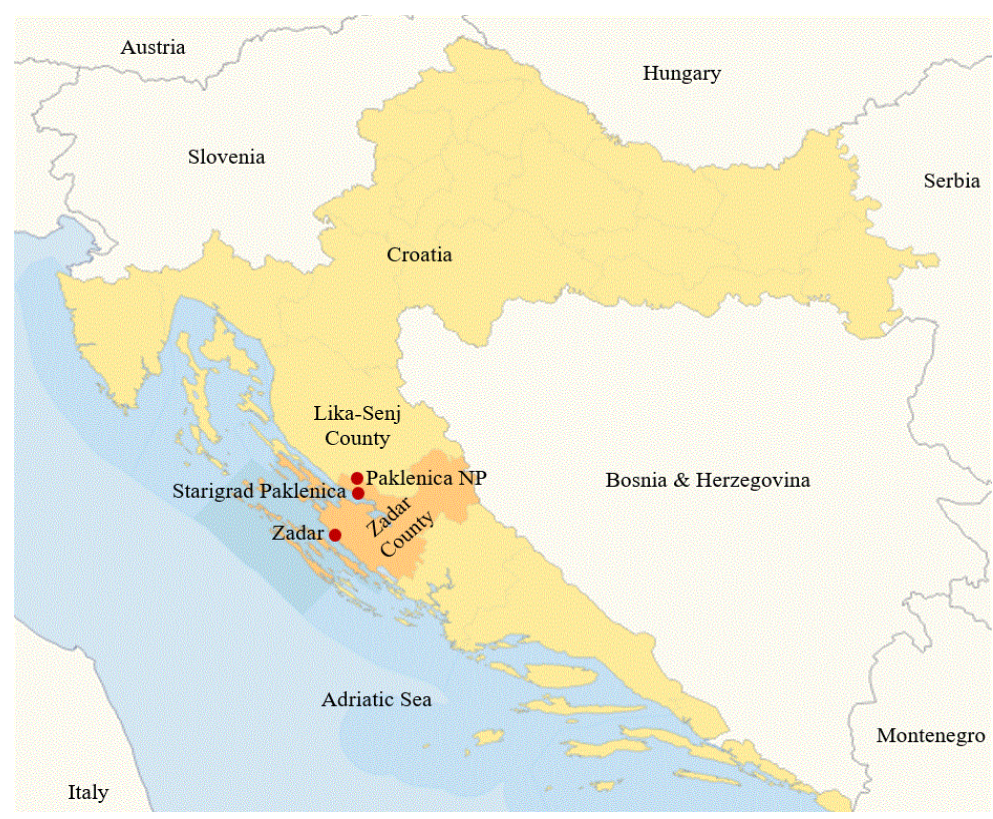

Source: Authors.

In 1962, the first and the most popular in the series of German western Winnetou movies, The Treasure of the Silver Lake, was filmed in ZC. In 2001, Michael Petzel recounted his own search for Winnetou treasure in his book The Road to the Silver Lake (Ger. Der Weg zum Silbersee), in which he described his own adventures while searching for the unmarked locations in Croatia where the movie had been filmed (Petzel 2001).

In 2016, two German authors (Brüderle and Scholten 2016) published a 160-page German-language guidebook Croatia - In the footsteps of Winnetou and Game of Thrones (Ger. Kroatien - Auf den Spuren von Winnetou und Game of Thrones). The guide explains and shows the locations of the movie sets in ZC and cities of Dubrovnik, Split, Zagreb, and Senj. Two Croatian authors (Tadej and Gabelica 2007) published another German-language guidebook on Winnetou, i.e. In the Footsteps of Winnetou in Croatia: 10 Winnetou Routes (Auf den Spuren Winnetous in Kroatien: 10 Routen Winnetous). To the best of our knowledge, neither national nor local tourism authorities in Croatia helped produce either guidebook.

Also, on the German website www.winnetoufeste.de dedicated to Winnetou festivals and events in Croatia, one can register for the annual Winnetou festival and book accommodation, as well as view the landscapes of $\mathrm{ZC}$ and photos from previous festivals. The Winnetou Museum opened in 2009 at Bluesun Holiday Village Alan, a hotel located in Starigrad Paklenica municipality (close to the actual locations where much of the filming took place) in gratitude to the actors, movie production crews who have filmed there for years, and fans of Karl May. In addition to many movie props, 
ToSEE - Tourism in Southern and Eastern Europe, Vol. 6, pp. 283-302, 2021.

M. Furčić, Lj. Pranić: WHAT THEY SAY AND WHAT THEY DO: COMPARING DESTINATION ...

photographs, and documentary material, visitors can explore two authentic hotel rooms occupied by Winnetou actors during filming.

Interestingly, Scalawag, a 1973 pirate adventure movie directed and starred by Kirk Douglas, was also filmed on location in Starigrad Paklenica and Paklenica NP in ZC.

\section{METHODOLOGY}

Using the Hudson and Ritchie (2006a) model for exploiting movie marketing opportunities, this study employed multimethod research, combining strategic conversations and observation.

\subsection{Strategic conversations}

First, 10 representatives of nine key stakeholder organizations in ZC's tourism and movie industries (Table 2) were interviewed in-person or by telephone in February of 2017 in order to answer the following research questions:

- Do key stakeholders of tourism development in ZC embrace the notion of movieinduced tourism?

- Has the concept of movie tourism been successfully integrated into ZC's tourist marketing activities?

- Is the movie tourism brand currently included in the umbrella tourism brand of ZC?

- Are tourism and movie stakeholders involved in the development of movie tourism in $\mathrm{ZC}$ ?

Table 2: List of Interviewed Participants

\begin{tabular}{|c|c|c|c|}
\hline Key Stakeholder & Position & $\begin{array}{c}\text { Organization } \\
\text { Type }\end{array}$ & $\begin{array}{l}\text { Organization } \\
\text { Location }\end{array}$ \\
\hline ZC DMO & Director & Public & Zadar, ZC \\
\hline ZC DMO & Information Officer & Public & Zadar, ZC \\
\hline $\begin{array}{l}\text { DMO of Starigrad Paklenica } \\
\text { municipality }\end{array}$ & Director & Public & $\begin{array}{c}\text { Starigrad } \\
\text { Paklenica, ZC }\end{array}$ \\
\hline City of Zadar DMO & Director & Public & Zadar, ZC \\
\hline Zadar Film Office & Director & Public & Zadar, ZC \\
\hline $\begin{array}{l}\text { INOVAcija - The Institution for } \\
\text { Development of Competence, } \\
\text { Innovation and Specialization of Zadar } \\
\text { County }\end{array}$ & Director & Public & Zadar, ZC \\
\hline $\begin{array}{l}\text { Bluesun Holiday Village Alan \& } \\
\text { Winnetou Museum }\end{array}$ & Marketing Director & Private & $\begin{array}{c}\text { Starigrad } \\
\text { Paklenica, ZC }\end{array}$ \\
\hline Mićanovi dvori rural homestead & Owner & Private & $\begin{array}{c}\text { Kruševo } \\
\text { (Obrovac), ZC }\end{array}$ \\
\hline $\begin{array}{l}\text { Department of Tourism and } \\
\text { Communication Studies at Zadar } \\
\text { University }\end{array}$ & $\begin{array}{l}\text { Team leader of the } \\
\text { Zadar Tourism } \\
\text { Development Strategy }\end{array}$ & Public & Zadar, ZC \\
\hline
\end{tabular}


ToSEE - Tourism in Southern and Eastern Europe, Vol. 6, pp. 283-302, 2021.

M. Furčić, Lj. Pranić: WHAT THEY SAY AND WHAT THEY DO: COMPARING DESTINATION ...

To answer the four research questions, the structured in-depth discussion comprised a total of 11 questions representing four factors and borrowed from O'Connor (2010). The first factor (movie-induced tourism) captures the extent to which movie tourism is accepted as a sustainable product of ZC and consists of four questions. The second factor (marketing activities) explores whether movie tourism is integrated into the tourist marketing activities of $\mathrm{ZC}$ and consists of three questions. The third factor (branding) determines if movie tourism is used as an independent destination brand in $\mathrm{ZC}$ and consists of 1 question. The fourth factor (stakeholder involvement) determines whether key stakeholders in ZC are collaborating and consists of three questions. The 11 interview questions (presented in detail in the results section) were emailed to each of the nine participants a week before the actual interview.

\subsection{Observations}

Seven websites were selected for this study's analysis - four DMO websites (i.e., Croatian National Tourist Board [CNTB], ZC, City of Zadar, and Starigrad Paklenica municipality), the Paklenica National Park (NP) website, the Bluesun Holiday Village Alan \& Winnetou Museum website, and the Mićanovi dvori rural homestead website. The rural homestead was included in the website analysis because it is located close to Winnetou's filming locations in ZC. In line with Hsieh and Shannon (2005), this study employed summative form of content analysis, which comprises (1) identifying and quantifying certain words or content in text, (2) interpreting the content, and (3) evaluating its quality by comparing the results of website content analysis with data collected through in-depth interviews of key destination stakeholders. Thus, in January of 2021, each website's homepage navigation menu and, subsequently, every page and subpage were manually browsed and their textual and visual elements content-analyzed for movie-related information in general and Winnetou in particular. Additionally, the search engine feature on five out of seven websites was queried using 'Winnetou,' 'movie,' and 'film' as search key words. The websites belonging to the NP and rural homestead did not have the search engine feature. All seven websites were surveyed in both English and German languages.

One brief note on the collection of data at two points in time that are five years apart. While the strategic conversations were conducted back in 2017, the website content analysis was performed in 2021 as a separate investigation to facilitate a more meaningful interpretation of the results collected in 2017. Stated differently, the two data collection points (i.e., 2017 and 2021) serve as snapshots in time. By allowing time to pass between the two data collection points, one would reasonably expect strong evidence that what has been said in 2017 can actually be confirmed in 2021 . 
ToSEE - Tourism in Southern and Eastern Europe, Vol. 6, pp. 283-302, 2021.

M. Furčić, Lj. Pranić: WHAT THEY SAY AND WHAT THEY DO: COMPARING DESTINATION ...

\section{RESULTS}

\subsection{Strategic conversations}

4.1.1. Research question 1 (RQ1): Do key stakeholders of tourism development in ZC embrace the notion of movie-induced tourism?

4.1.1.1. Interview question 1 (IQ1): Will the phenomenon of movie tourism continue to grow due to the global distribution and viewing of movies?

All respondents agree that movie tourism will continue to grow because both tourism entities and moviemakers benefit from movies. One respondent stated that movie is a fiction that people need in order to enrich their everyday life and to escape reality. All respondents believed that the movie industry around the world is constantly growing and generating billions of dollars in revenue, and that growth is accompanied by movie tourism.

Respondents also agreed that promoting a destination through a movie is one of the best forms of promotion. Some of the stakeholders emphasized that movie tourism does not suffer from seasonality and note that people are emotionally attached to the characters and movie/series locations. That makes this form of tourism very popular and can turn an otherwise touristically unattractive or unknown location into a tourist hotspot. One example is the Korean reality show The Romantic in Croatia that was filmed in Croatia and shown on Korean television, with one married couple receiving a free honeymoon in Croatia, ultimately resulting in a large number of Korean visitors and shooting of additional two shows.

4.1.1.2. IQ2: Some believe that, as people read less, what is shown in movies, on television, and other media will become even more important?

One participant opined that although people spend more time watching video content than reading, that the amount of videos fighting for our attention is increasing dramatically, thus only the best ones will manage to break through. Others stated that, due to the growing importance of what is shown in movies or on television, even greater efforts are needed to position Croatia as an attractive filming location, because such endeavors can spur tourist demand.

4.1.1.3. IQ3: The limited research published so far shows that movie tourism can have significant benefits for destination development?

Approximately half of all respondents cited how NZ has turned into an premier tourist destination thanks to the Lord of the Rings trilogy. They stated that NZ has seen an $10 \%$ annual increase in visitors since 1998, and the village of Hobbiton continues to attract many visitors. Scotland is also mentioned, where Braveheart was shot. In Croatia, Dubrovnik has increased its popularity among tourists thanks to the Game of Thrones series.

One respondent argued that Winnetou provides the best example of benefits from the movie-induced tourism to a destination. Although 50 years have passed since the filming, tourists still visit the filming locations, the Winnetou Museum in Starigrad Paklenica, 
ToSEE - Tourism in Southern and Eastern Europe, Vol. 6, pp. 283-302, 2021.

M. Furčić, Lj. Pranić: WHAT THEY SAY AND WHAT THEY DO: COMPARING DESTINATION ...

and there are numerous tourist programs and routes that attract a large number of visitors every year. In 2015, a new Winnetou trilogy was shot at the same locations, thus pointing not only to the popularity of the movies, but also to the potential for further development of movie tourism.

One respondent expressed that movie tourism has a significant benefit for a destination because, in addition to generating more tourist arrivals at filming locations, it can also lead to a production of new souvenirs. He further emphasized that movie can function as a tourist resource on its own - therefore, a destination does not have to have the sea, attractions or other resources. Only a movie with a loyal fan base is enough to spark demand for a destination.

4.1.1.4. IQ4: Movies allow destinations to enhance their tourism potential. Did this happen in $\mathrm{ZC}$ ?

Most respondents stated that the tourist potential of $\mathrm{ZC}$ has improved and cite Winnetou movies as an example, while some respondents disagreed, stating that the positive effects will definitely be felt in the future. Apparently, Winnetou in ZC is a great example of a movie-induced tourism. Respondents stated that Winnetou movies are considered the most watched films of all time in Germany, and since 2007, hundreds of Karl May fans gather annually in Starigrad Paklenica. Many tourists arrive in the Starigrad Paklenica area specifically to visit the filming locations and have an unforgettable experience.

2016 marked the 50th anniversary of the shooting of the first Winnetou. In June of 2016, the ZC DMO, in cooperation with the Starigrad Paklenica DMO and CNTB, organized a three-day trip for foreign journalists to further promote $\mathrm{ZC}$ and Croatia in the Germanspeaking countries. A group of 13 journalists from Germany, Austria and Switzerland visited numerous Winnetou-related locations. This lead to numerous articles, mainly in print, but also in electronic media in the German-speaking countries. Some respondents believe that Winnetou has improved the tourist potential of ZC and that this is shown by increased patronage to the Winnetou Museum in Starigrad Paklenica and Paklenica NP by German tourists, many of whom come to these two sites specifically because of Winnetou.

4.1.2. RQ2: Has the concept of movie tourism been successfully integrated into ZC's tourist marketing activities?

4.1.2.1. IQ5: Given how films can raise awareness of places and influence decisionmaking processes, marketers are increasingly working with film producers to promote their destinations as possible film locations. Did this happen to you?

One respondent said that, as part of INOVAcija, an Institution for the Development of Competences, Innovations and Specialization of ZC, in September 2014 the Zadar Film Office was established, the first of its kind in Croatia, with the aim of attracting film projects. The ZC DMO does not cooperate directly with film producers. He further stated that contacts with film producers fall within the competence of ZC Film Office, which provides logistical and technical support to interested productions in ZC. It was also said that ZC DMO is in constant contact with the Film Office and closely cooperates on numerous projects that take place within $\mathrm{ZC}$. 
ToSEE - Tourism in Southern and Eastern Europe, Vol. 6, pp. 283-302, 2021.

M. Furčić, Lj. Pranić: WHAT THEY SAY AND WHAT THEY DO: COMPARING DESTINATION ...

4.1.2.2. IQ6: It is important that movie/television is involved in tourism / destination marketing planning, especially in small communities that are most sensitive to development?

Starigrad Paklenica is a good example of how a smaller community profited thanks to the movie industry. Although 50 years have passed since the movies' release, Winnetou continues to strongly attract many fans to the smaller communities across ZC. It should not be forgotten that Winnetou movies are still shown on German television, and new generations of Winnetou lovers are being born. It was also said that Starigrad Paklenica DMO carefully plans all its marketing activities, especially those related to the Winnetou brand, and of course that it is being mirrored by ZC DMO and CNTB. One respondent stated that the ZC Tourism Master Plan did not list movie tourism as a special form to be developed, but the plan listed the effects that the Winnetou series had on the area where it was filmed, and the ZC Destination Marketing Action Plan has not been enacted yet.

4.1.2.3. IQ7: Can you elaborate on how your current tourism marketing strategy intends to improve ZC as a tourist destination?

In addition to the Croatian Tourism Development Strategy 2014-2020, and the ZC Tourism Development Master Plan, the marketing activities of ZC DMO in 2017 continue with a focus on special interest products to strengthen the brand and create strong reasons to visit in the shoulder season. The key activities are standardization and brand creation. In that respect, ZC DMO implements several marketing projects for the development of special interest tourism, specifically lifestyle, active (outdoor or adventure), cycling, trail, rural, and nautical forms of tourism. The strong presence of these products will continue in both online and offline marketing channels.

In the last few years, a regional Film Office has been operating in $\mathrm{ZC}$, the only one in Croatia, which promotes the region as a movie-attractive destination. One of the examples of destination promotion through movies is the cooperation of the Film Office, $\mathrm{ZC} \mathrm{DMO}$, and the movie producers related to the premiere of the Belgian movie River Upstream at the end of last year.

Furthermore, in Starigrad Paklenica municipality, during the last ten years there has been some strong destination promotion through Winnetou movies filmed both in the 1960s and in 2015. It is stated that a tourist product Following The Trails Of Winnetou is being formed, which today includes interpreted film locations in the area, promotional material with a map of locations, a permanent exhibition within the Bluesun Holiday Village Alan and an annual meeting of fans with a range of content.

Importantly, local tourist businesses have joined in, offering tours of movie locations, thematic programs, souvenirs, etc. Furthermore, in order to promote the area as a movie tourism destination, a Film Park was created to tell the story about many motion pictures that were produced in the area in recent decades. Overall, marketing covers key tourist products of the destination, such as summer tourism and active holidays, with movies as part of the area's tourist attractions that contribute to the area's tourist patronage. 
ToSEE - Tourism in Southern and Eastern Europe, Vol. 6, pp. 283-302, 2021.

M. Furčić, Lj. Pranić: WHAT THEY SAY AND WHAT THEY DO: COMPARING DESTINATION ...

4.1.3. RQ3: Is the movie tourism brand currently included in the umbrella tourism brand of $\mathrm{ZC}$ ?

4.1.3.1. IQ8: Is Winnetou, as a brand, or some other movie, currently included in ZC tourist destination brand?

All respondents agree that Winnetou as a brand is included in ZC brand and state that the Winnetou brand is a unique, finished product of movie tourism in ZC. Moreover, the offer of local agencies meets the needs of the market and offers programs that present movie locations. That is why Winnetou is an example of movie tourism that has been going on for years, and together with Game of Thrones, it is the only such example in Croatia. There are trails on mount Paklenica, photo safari tours on the historic roads of mount Velebit, a Winnetou Museum inside Bluesun Holiday Village Alan, a movie map that is available inside the Starigrad Paklenica DMO offices, canoeing or boating along the emerald green Zrmanja river (named Rio Pecos in Winnetou), stunning views from the top of the Zrmanja river canyon (named Pueblo plateau in Winnetou), enjoying the waterfall inside Plitvice Lakes NP (named Silver Lake in Winnetou), and other experiences that tourists / fans expect when visiting movie locations in Croatia.

4.1.4. RQ4: Are tourism and movie stakeholders involved in the development of movie tourism in $\mathrm{ZC}$ ?

4.1.4.1. IQ9: If there is strong collaboration among DMOs, the movie industry, and film offices, the results can be very effective?

NZ and Lord of the Rings trilogy are cited as a great and world-famous example of cooperation between DMOs and the movie industry, and the astonishing success it has achieved around the world has created ideal conditions for tourism development in NZ. Tourist organizations made excellent use of this fantastic promotion, so the collaboration continued in the next trilogy of The Hobbit, and the most commercial film of all time, Avatar.

Croatia is also mentioned as an example where steps have been taken in that direction because the Croatian Audiovisual Center (HAVC, the government-backed strategic agency for the audiovisual sector in Croatia), which is tasked with attracting foreign movie and television crews to the country, introduced incentives for the film industry in 2012. Croatia is also on the world map of desirable film locations, especially the city of Dubrovnik, which is the best possible tourist promotion for Croatia. Thanks to the incentives of HAVC, many foreign productions pick Croatia for their movie sets.

One respondent states that in the case destination promotion through Winnetou movies, they had cooperation with CNTB, which significantly helped them in product development and promotion. It was noted that the Winnetou story does not refer to only one destination as a filming location, but numerous locations throughout Croatia served as filming locations, which positioned Croatia as the 'Homeland of Winnetou.' However, most of these tourism promotional efforts were realized in the area of Starigrad Paklenica municipality. While some interviewees believed that the Film Office successfully cooperates with CNTB, one respondent states that such collaboration does not currently 
ToSEE - Tourism in Southern and Eastern Europe, Vol. 6, pp. 283-302, 2021.

M. Furčić, Lj. Pranić: WHAT THEY SAY AND WHAT THEY DO: COMPARING DESTINATION ...

exist. However, collaboration at the national level is the only way to successfully develop movie tourism at both regional and national levels.

4.1.4.2. IQ10: In order to maximize the movie tourism potentials, tourism and movie stakeholders should work together, and tourism stakeholders in particular must take a more active strategic approach to the movie tourism concept?

Not only is the cooperation at ZC level excellent, but their activities are in many cases interlaced, and synergy is achieved. The ZC DMO successfully cooperates with the Film Office in Zadar. It was also highlighted that ZC DMO annually hosts about two hundred representatives of foreign media, who publish articles, photos, recordings, and videos promoting almost all parts of ZC. What is more, together with travel agencies, ZC DMO participates in the development of specialized programs for movie tourism enthusiasts and promotes these programs through all of its channels.

One participant stressed that collaboration has already been accomplished, but that it is necessary and desirable that all tourism stakeholders are even more active in order to create and strengthen the movie-induced tourism.

\subsubsection{IQ11: Can you explain your relationship with other tourism stakeholders?}

All representatives claim they are well interconnected and most activities are jointly carried out. The Zadar Film Office and ZC DMO collaborate in projects to promote ZC through movies, commercials, catalogs or the like, which promote the beauties of $\mathrm{ZC}$ as a tourist destination. One participant accentuated that Bluesun Holiday Village Alan is a partner of ZC DMO in numerous activities, from advertising, appearances at fairs, hosting foreign journalists, and many others. Additionally, ZC DMO and the Department of Tourism and Communication Studies at Zadar University jointly participated in a close partnership in the development of the ZC Tourism Development Master Plan. The university department conducts research and prepares surveys whose findings DMOs use as a starting point for analysis and planning.

\subsection{Observations}

On each of the seven websites, there were no significant differences in both textual and visual content between English and German webpages. The website content analysis revealed that two websites do not contain any information on Winnetou or any other movie-related information. These two websites belong to Paklenica NP (https://www.nppaklenica.hr/en/) and Mićanovi dvori rural homestead (https://en.micanovidvori.com/). The City of Zadar DMO website (https://zadar.travel/) only posts an announcement about the Students Ethnographic Film Festival in May of 2021, an event that is in no way related to either Winnetou or any filming location anywhere. While the summary of content-analysis is provided in Table 3 , detailed findings are described in the remainder of this section. 
ToSEE - Tourism in Southern and Eastern Europe, Vol. 6, pp. 283-302, 2021.

M. Furčić, Lj. Pranić: WHAT THEY SAY AND WHAT THEY DO: COMPARING DESTINATION ...

Table 3: Summary of Content-Analysis

\begin{tabular}{ll}
\hline Website & $\begin{array}{l}\text { Presence and quality of the Winnetou-related } \\
\text { promotional content }\end{array}$ \\
\hline $\begin{array}{l}\text { Croatia's national DMO } \\
\text { Zadar County DMO }\end{array}$ & $\begin{array}{l}\text { mention. Poor quality (non-actionable) } \\
\text { City of Zadar DMO }\end{array}$ \\
$\begin{array}{l}\text { DMO of Starigrad Paklenica } \\
\text { municipality }\end{array}$ & None \\
$\begin{array}{l}\text { Paklenica National Park } \\
\text { Bluesun Holiday Village Alan \& } \\
\text { Winnetou Museum }\end{array}$ & None \\
Mićinovića dvori rural homestead & 2 mentions. Poor quality (non-actionable)
\end{tabular}

Content analysis of the website belonging to the Bluesun Holiday Village Alan \& Winnetou Museum (https://www.holiday-village-alan.com/en/) produced two meaningful results, both located under the main 'Explore Destination' drop-down menu on the website's homepage. The first one is 'Winnetou Museum', located one level below the main 'Explore Destination' menu. The second one is 'Winnetou Karl May Films Tour', located two levels below the main 'Explore Destination' menu, under the 'Day Trips' drop down list. The Winnetou Museum webpage contains several images of the museum and some very basic non-actionable textual content that can equally be found on Wikipedia (Figure 3). The Winnetou Karl May Films Tour is a 2015 celebration of the $50^{\text {th }}$ anniversary of filming Winnetou in the area, thus almost six years outdated.

Figure 3: Winnetou-related content on Bluesun Holiday Village Alan \& Winnetou Museum website

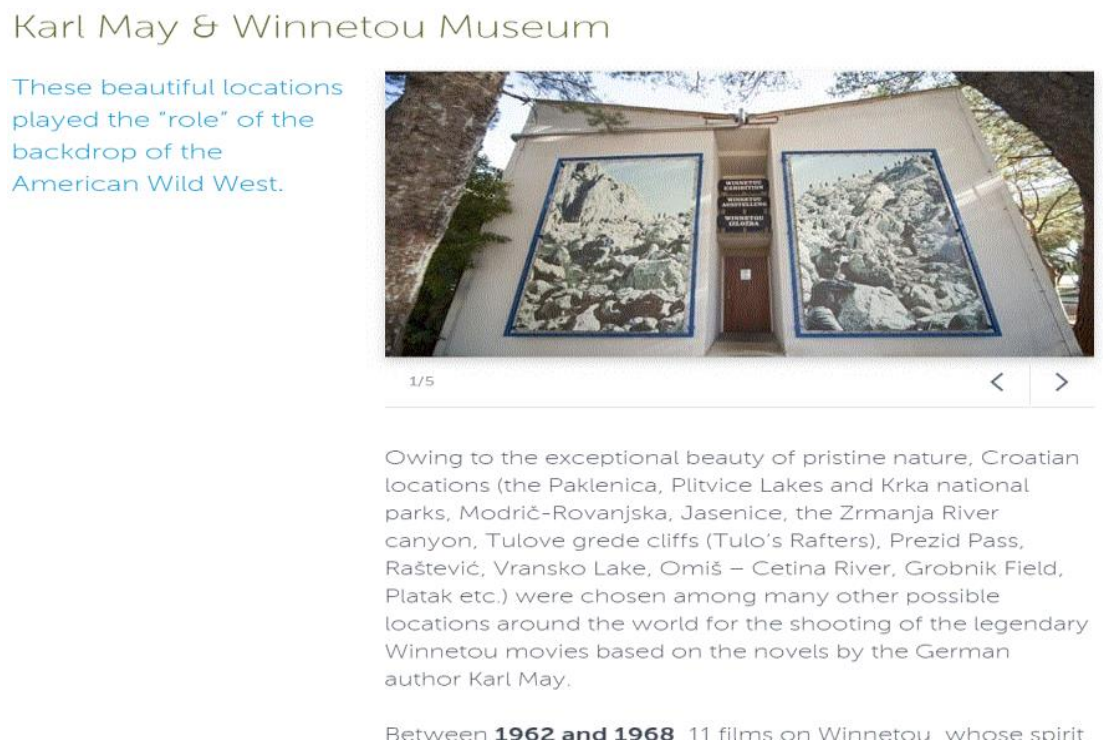

Source: https://www.holiday-village-alan.com/en/karl-may-museum.aspx 
ToSEE - Tourism in Southern and Eastern Europe, Vol. 6, pp. 283-302, 2021.

M. Furčić, Lj. Pranić: WHAT THEY SAY AND WHAT THEY DO: COMPARING DESTINATION ...

The ZC DMO website (https://www.zadar.hr/en) mentions Winnetou in four different locations. All four mentions are located two or more levels down below the main 'Destinations' drop-down menu on the website's homepage. The first one is two levels below the main 'Destinations' drop-down menu on the website's homepage, i.e. on the 'Paklenica Riviera' webpage (https://www.zadar.hr/en/destinations/paklenica-riviera) that begins with a two-sentence description, with the first sentence reading "Visit the home of captivating legends and thrilling adventures, sandy and pebble beaches, hundreds of plant and animal species listed by UNESCO and Winnetou movies!" If one scrolls midway down that same Paklenica Riviera webpage, he will discover the title "The Trails of Winnetou: Ride like Winnetou!", followed by two-paragraph narrative containing some basic nonactionable textual content (Figure 4). The third Winnetou entry is found three levels below the home page (https://www.zadar.hr/en/destinations/paklenica-riviera/jasenice/jasenice), where the one-sentence description reads "Under the crags of the Velebit extending towards the sea lies the locality of Jasenice where guests can relive the scenes of the famous western serial Winnetou along the Zrmanja River Canyon." The fourth Winnetou entry can be found two levels below the main 'Experience' drop-down menu on the website's homepage (https://www.zadar.hr/en/experience/national-nature-parks/nature-park-velebit), where the two-paragraph description of Velebit Nature Park ends with the following sentence: "And speaking of mystery, the famous Winnetou film were shot here also!"

\section{Figure 4: Winnetou-related content on ZC DMO website}

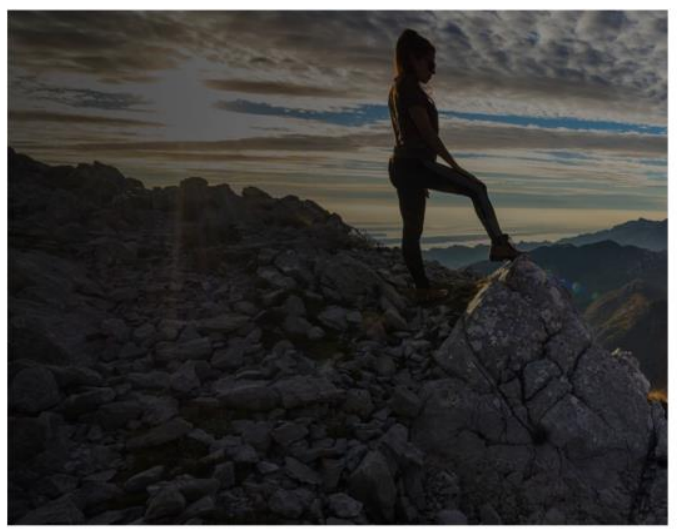

\section{The Trails of Winnetou Ride like Winnetoul}

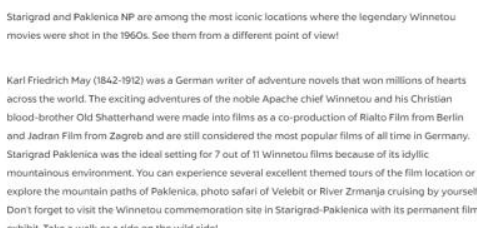

Source: https://www.zadar.hr/en/destinations/paklenica-riviera

The Starigrad Paklenica DMO website (http://www.rivijera-paklenica.hr/en) provides Winnetou-related content in a single location that can be reached via two different entrypoints, both located on the homepage. The first entry-point is directly below the main 'Attractions' drop-down menu on the website's homepage. The second entry-point is presented as one of six small squared images (depicting a Native American) located at the foot of the main image on the website's homepage (Figure 5). Once you click through either entry-point, you land on the webpage where the Winnetou-related content is split into six consecutive sections. Each of the six sections contains six of fewer Winnetourelated images and some very basic and non-actionable textual content. One of the six sections is titled 'Annual Karl May Fan Convention on Film Locations in Croatia' and 
ToSEE - Tourism in Southern and Eastern Europe, Vol. 6, pp. 283-302, 2021.

M. Furčić, Lj. Pranić: WHAT THEY SAY AND WHAT THEY DO: COMPARING DESTINATION ...

provides a downloadable two-page German-only brochure in PDF. The brochure describes and illustrates a five-day program packed with various activities and visits to the actual filming locations. However, both the brochure and program seem to be the product of a Winnetou fan club in Germany that was conveniently added to the Starigrad Paklenica DMO webpage.

Figure 5: Winnetou-related content on Starigrad Paklenica DMO website

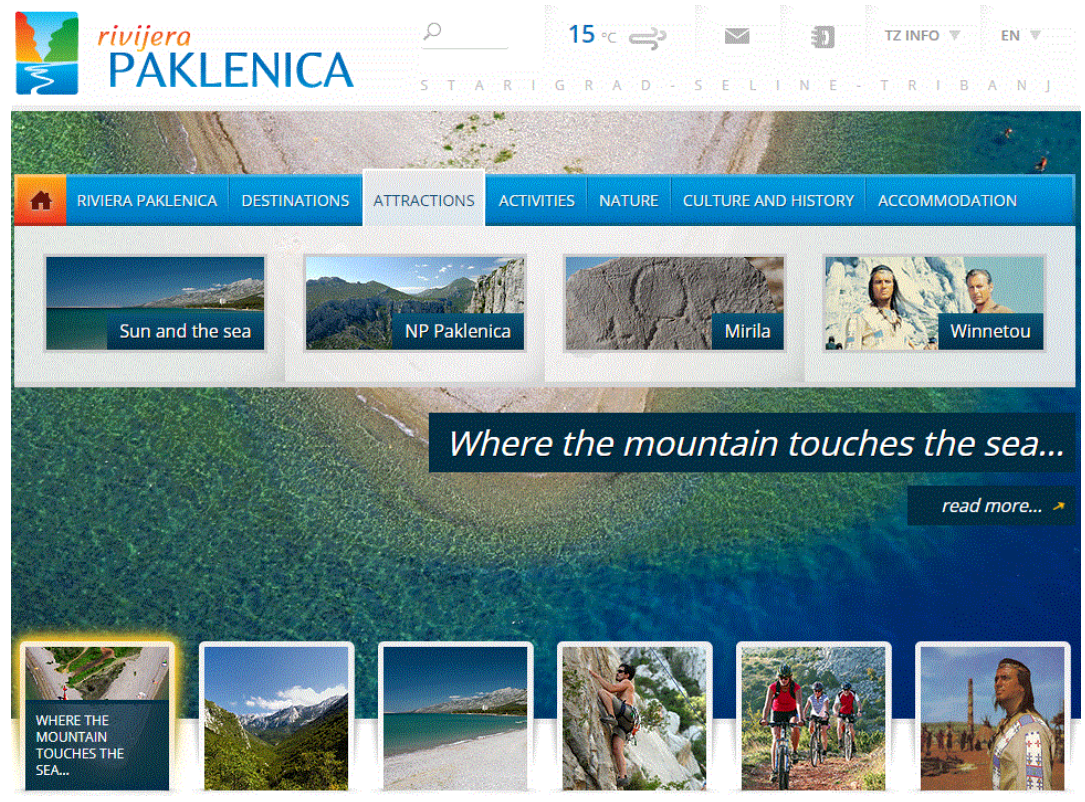

Source: http://www.rivijera-paklenica.hr/en

The CNTB website (https://croatia.hr/en-GB/trip-ideas/Behind-scenes) Winnetou- and movie-related content under the main 'Trip Ideas' menu, under the 'Behind the scenes' entry. Therein, once you scroll down to the lower half of the page, you will discover the following two-sentence description: "In the beautiful Paklenica National Park, you can retrace the footsteps of the Native American hero Winnetou of the cult 1960s films. The filming of a new trilogy about the character, created by Karl May, was begun in the area in 2015, as well as in the regions of Istria, Lika and Gorski Kotar." Again, no actionable information or links are provided for the reader.

\section{CONCLUSION}

The main objectives of this research were (a) to assess the perceptions of key destination stakeholders regarding the level of integration of movie-induced tourism and destination marketing after a movie's release, and (b) to compare their perceptions to what can actually be observed, in a relatively popular movie-shooting destination such as Zadar County (ZC), Croatia. In order to accomplish the two objectives, this study combined qualitative and quantitative approaches. It is believed that a combination of these 
ToSEE - Tourism in Southern and Eastern Europe, Vol. 6, pp. 283-302, 2021.

M. Furčić, Lj. Pranić: WHAT THEY SAY AND WHAT THEY DO: COMPARING DESTINATION ...

methods maximizes the accuracy of the findings, with quantitative/qualitative research (i.e., website content analysis) providing a reality check of the issues explored by another qualitative research (i.e., strategic conversations; O’Connor et al. 2008; Özdemir and Adan 2014).

Based on strategic conversations (i.e., in-depth interviews) with representatives of key stakeholder organizations in ZC, it appears that both tourism and movie industries embrace the notion of movie-induced tourism, believe that the concept of movie tourism been successfully integrated into ZC's tourist marketing activities, consider that the movie tourism brand is currently included in the umbrella tourism brand of $\mathrm{ZC}$, and perceive that tourism and movie stakeholders are involved in the development of movie tourism in ZC. However, the results of content analysis of key tourism websites in ZC (and CNTB) fail to corroborate the views expressed by representatives of key stakeholder organizations.

For instance, when asked about how the current tourism marketing strategy intends to improve ZC as a tourist destination, the respondents point to a number of activities, such as interpreted film locations in the area, promotional material with a map of locations, a permanent exhibition within the Bluesun Holiday Village Alan, an annual meeting of fans with a range of content, tours of movie locations, thematic programs, souvenirs, a Film Park telling the story about many motion pictures that were produced in the area, etc. The website content analysis reveals that actionable information, such as movie maps, location guides, guided and self-guided tours, movie walks, tour packages, museum hours, a dedicated movie website, and other movie-related services (e.g., a hotel that was used by the cast and production crew during filming) are nowhere to be found.

Another example is when the respondents are asked whether Winnetou, as a brand, or some other movie, is currently included in ZC tourist destination brand. Again, the list of supposed examples of Winnetou's inclusion in destination branding efforts, almost identical to the narrative provided in the previous paragraph, goes on and on. The website content analysis reveals that actionable information is nowhere to be found. That said, while the website belonging to the Bluesun Holiday Village Alan is in fact home to a Winnetou museum, other key tourism websites that were content analyzed in this study lack actionable information about the museum. This and the previous example are just two glimpses of the mismatch between what respondents claim that they are doing and what can actually be observed in terms of movie-related tourism in ZC.

Interestingly, while ZC key stakeholders are familiar with the success experienced by New Zealand and Scotland, it begs the question whether they actually ever visited the DMO websites of these market leader destinations in the area of movie-induced tourism. Compared to the official websites of national tourism organizations of New Zealand, Scotland, and Great Britain (https://www.newzealand.com/uk/film-in-new-zealand/, https://www.visitscotland.com/see-do/attractions/tv-film/, and https://www.visitbritain .com/gb/en/things-to-do/film-and-tv, respectively), DMO websites in Zadar County and the website of Croatia's national tourism organization clearly lack creativity and understanding of the nature of movie tourism experiences. It is hoped that the results of this research will challenge the key movie tourism stakeholders in ZC (and Croatia in general) to harness the potentials of movie-induced tourism. 
ToSEE - Tourism in Southern and Eastern Europe, Vol. 6, pp. 283-302, 2021.

M. Furčić, Lj. Pranić: WHAT THEY SAY AND WHAT THEY DO: COMPARING DESTINATION ...

In terms of this study's limitations, this research explored and found discrepancies between destination marketers' perceptions and their actual behaviors. It did not investigate the causes of these discrepancies. According to Gretzel et al. (2000) and Hudson and Ritchie (2006a), destination marketers often have to cope with limited financial and human resources. Therefore, future studies should explore whether and to what degree the financial, HR or some other reasons impede harnessing the potentials of movie-induced tourism.

\section{REFERENCES}

Beeton, S. (2010), "The Advance of Film Tourism", Tourism and Hospitality Planning \& Development, Vol. 7, No. 1, pp. 1-6. doi: 10.1080/14790530903522572

Beeton, S. (2006), "Understanding film-induced tourism", Tourism Analysis, Vol. 11, pp. 181-188.

Brüderle, D. and Scholten, M. (2016), Kroatien - Auf den Spuren von Winnetou und Game of Thrones, Schueren Verlag.

Busby, G. and Klug, J. (2001), "Movie-induced tourism: The challenge of measurement and other issues", Journal of Vacation Marketing Vol. 7, No. 4, pp. 316-332.

Cardoso, L., Estevão, C., Fernandes, C. and Alves, H. (2017), "Film-induced tourism: a systematic literature review”, Tourism \& Management Studies, Vol. 13, No. 3, pp. 23-30. doi: 10.18089/tms.2017.13303

Carl, D., Kindon, S. and Smith, K. (2007), "Tourists' Experiences of Film Locations: New Zealand as 'MiddleEarth",, Tourism Geographies: An International Journal of Tourism Space, Place and Environment, Vol. 9, No. 1, pp. 49-63. doi: 10.1080/14616680601092881

Carlucci, G. (2012), "Una vacanza da film. Il cine-turismo e' la nuova strada da propore", 10 convegno internazionale sul cineturismo, Ischia.

Connell, J. and Meyer, D. (2009), "Balamory revisited: An evaluation of the screen tourism destination-tourist nexus", Tourism Management, Vol. 30, pp. 194-207.

Domínguez-Azcue, J., Almeida-García, F., Pérez-Tapia, G. and Cestino-González, E. (2021) "Films and Destinations - Towards a Film Destination: A Review", Information, Vol. 12, No. 1, p. 39 https://doi.org/10.3390/info12010039

El Samie Mohamed, H.A. (2016), "Film-induced tourism: investigating the role of destination management organizations in Egypt", Journal of Association of Arab Universities for Tourism and Hospitality, Vol. 13, No.1, pp. 151-164.

Girvin, S. (2019), Game of Thrones is 'game changer' for NI tourism, BBC News, viewed 13 April 2021, https://www.bbc.com/news/uk-northern-ireland-48343910

Gretzel, U., Yuan, Y.L. and Fesenmaier. D.R. (2000), "Preparing for the New Economy: Advertising Strategies and Change in Destination Marketing Organizations", Journal of Travel Research, Vol. 39, No. 2, pp. 146-156.

Grihault, N. (2003), "Film Tourism - The Global Picture", Travel \& Tourism Analyst, Vol. 5, pp. 1-22.

Hahm, J. and Wang, Y. (2011), "Film-Induced Tourism as a Vehicle for Destination Marketing: Is it Worth the Efforts?", Journal of Travel \& Tourism Marketing, Vol. 28, No. 2, pp. 165-179, doi: $10.1080 / 10548408.2011 .546209$

Hsieh, H-F. and Shannon, S.E. (2005), "Three Approaches to Qualitative Content Analysis", Qualitative Health Research, Vol 15. No. 9, pp. 1277-1288. doi: 10.1177/1049732305276687

Hudson, S. and Ritchie, J.R.B. (2006a), "Promoting destinations via film tourism: An empirical identification of supporting marketing initiatives", Journal of Travel Research, Vol. 44, No. 4, pp. 387-396.

Hudson, S. and Ritchie, J.R.B. (2006b), "Film tourism and destination marketing: the case of Captain Corelli's Mandolin", Journal of Vacation Marketing, Vol. 12, No. 3, pp. 256-268.

Michael, N., Balasubramanian, S., Michael, I. and Fotiadis, A. (2020), "Underlying motivating factors for movie-induced tourism among Emiratis and Indian expatriates in the United Arab Emirates", Tourism and Hospitality Research, Vol. 20, No. 4, pp. 435-449. doi 10.1177/1467358420914355

Modiano, D. (2013), Film tourism \& travel motivation, viewed 27 March 2021, https://aboutourism.wordpress.com/tag/travelsat/

Morgan, N. and Pritchard, A. (1998), Tourism Promotion and Power - Creating Images, Creating Identities, John Wiley \& Sons, Chichester.

Özdemir, G. and Adan, Ö. (2014), "Film Tourism Triangulation of Destinations", Procedia - Social and Behavioral Sciences, Vol. 148, pp. 625-633. 
ToSEE - Tourism in Southern and Eastern Europe, Vol. 6, pp. 283-302, 2021.

M. Furčić, Lj. Pranić: WHAT THEY SAY AND WHAT THEY DO: COMPARING DESTINATION ...

O'Connor, N. (2010), A Film Marketing Action Plan (FMAP) for Film Induced Tourism Destinations, Doctoral Thesis, Technological University Dublin, doi:10.21427/D7PS4V

O'Connor, N., Flanagan, S. and Gilbert, D. (2008), "The Integration of Film-induced Tourism and Destination Branding in Yorkshire, UK", International Journal of Tourism Research, Vol. 10, pp. 423-437.

Petzel, M. (2001), Der Weg zum Silbersee. Drehorte und Dreharbeiten der Karl May Filme, Schwarzkopf und Schwarzkopf Verlag, Berlin.

Riley, R., Baker, D. and Van Doren, C.S. (1998), "Movie Induced Tourism”, Annals of Tourism Research, Vol. 25, No. 4, pp. 919-935.

Spears, D.L., Josiam, B.M., Kinley, T. and Pookulangara, S. (2013), “Tourist See Tourist Do: The Influence of Hollywood Movies and Television on Tourism Motivation and Activity Behavior", Hospitality Review, Vol. 30, No. 1, pp. 53-74.

Tadej, V. and Gabelica, D. (2007), Auf den Spuren Winnetous in Kroatien: 10 Routen Winnetous, Jadran Film Zagreb.

TCI Research (2018), 80 Million International Travellers, viewed 19 April 2021, http://xl4z.mj.am/nl2/xl4z/lgs45.html?hl=fr

Tooke, N. and Baker, M. (1996), "Seeing is believing: the effect of film on visitor numbers to screened locations", Tourism Management, Vol. 17, No. 2, pp. 87-94.

VisitBritain (2017), VisitBritain launches marmalade-inspired tourism campaign ahead of Paddington 2 viewed 12 April 2021, https://www.visitbritain.org/visitbritain-launches-marmalade-inspiredtourism-campaign-ahead-paddington-2

Martina Furčić, Univ. Spec. Oec.

Miroslava Krleže 3c, 23000 Zadar, Croatia

+385-098-571176

martinafurcic@gmail.com

Ljudevit Pranić, PhD, Associate Professor

University of Split, Faculty of Economics, Business and Tourism

Department of Tourism and Economy

Cvite Fiskovića 5, 21000 Split, Croatia

+385-21-430749

ljudevit.pranic@efst.hr 